DOI https://doi.org/10.30525/978-9934-26-074-2-12

\title{
ПРИНЦИП СПРАВЕДЛИВОСТІ ТА ПРИНЦИП ЗАКОННОСТІ В КОНСТИТУЦІЙНОМУ ПРАВІ УКРАЇНИ
}

\author{
Шелевер Н. В. \\ кандидатка юридичних наук, дочентка, \\ дочентка кафедри адміністративного, \\ фінансового та інформаційного права \\ ДВНЗ «Ужсгородський національний університет» \\ м. Ужсгород, Украӥна
}

У зв'язку із проведенням судової реформи в Україні, пандемією коронавірусу COVID-19 актуальним питанням сьогодення є дослідження принципу справедливості та принципу законності в конституційному праві. В Основному Законі Україні дані принципи закріплені, проте не реалізуються на практиці належним чином. Так, у ст. ст. 6, 8, 19, 68 Конституції України закріплений принцип законності. Проте на практиці ми є свідками, коли нормативно-правові акти не відповідають Конституції України, є численні порушення 3 боку органів державної влади та місцевого самоврядування. Про це свідчить велика кількість справ, які розглядаються адміністративними судами за участю представників влади.

Щодо принципу справедливості, то він взагалі не закріплений в Конституції України. Лише у ст. 95 Основного Закону України зазначено, що бюджетна система України будується на засадах справедливого i неупередженого розподілу суспільного багатства між громадянами і територіальними громадами.

На думку Погребняка С., «водночас слід нагадати, що ціла низка конституційних вимог безпосередньо випливає 3 принципу справедливості - це свідчить також про непряме закріплення цього принципу в Конституції. Наприклад, ідея справедливості конкретизується в принципі non bis in idem, закріпленому в ст. 61 Конституції України. Принцип справедливості також обумовлює обов'язок оприлюднення нормативноправових актів (ч. 3 ст. 57 Конституції), загальну заборону зворотної дії законів (ч. 1 ст. 58 Конституції), право не бути примушеним до свідчень проти себе (ч. 1 ст. 63 Конституціi), право на судовий захист (ст. 55 Конституції) та ін.» [1, с. 31-32].

Як справедливо зазначає Івановська А.: «Провідне місце в регулюванні суспільних відносин у будь-якій демократичній державі належить Конституції. Вона відіграє правоутворюючу роль, є своєрідним 
центром правової системи і тому має вищу юридичну силу, пряму дію, застосовується на всій території держави. Приписи Конституції повинні постійно і повсюдно здійснюватися без будь-яких винятків за підтримки не тільки органів публічної влади, а й громадськості. Дотримання i беззаперечне виконання іiі норм у правореалізаційному процесі $\epsilon$ найважливішою умовою підтримки загального режиму законності в країні» [2, с. 44].

Зміст законності полягає у відповідності будь-якої діяльності правовому закону. Законність - це характеристика правотворчої i правореалізуючої діяльності. Дотримання законів - вища справедливість для Сократа. Навіть несправедливий закон вимагає підпорядкування. Сократ вважає, що принцип законності - це принцип обов'язкового підпорядкування. На його думку, закон визначається через підпорядкування.

На думку Баглая М., Туманова В., законність - це процес суворого дотримання конституції і законів, а також інших правових актів усіма органами державної влади, місцевого самоврядування, посадовими особами і громадянами [3, с. 143].

Як справедливо вважає Поленіна С., законність залежить від якості самих законів. Закон є якісним у тому випадку, якщо він відповідає суспільним потребам. Він повинен дійсно регулювати суспільні відносини у відповідності до цілей, які закладені у самому законі. Якість закону - поняття юридичне. Проте враховуючи нерозривний зв'язок законодавчої стратегії з реалізацією політичних рішень, які повинні базуватися у свою чергу на пізнанні соціально-економічних процесів виявляється необхідним трактування терміну «якість закону» також під кутом зору його політичних і соціальних характеристик. Таким чином, шляхи підвищення якості закону знаходяться у всіх трьох площинах соціальній, політичній і юридичній $[4$, с. 7].

Закон діє тоді, коли він виконується. Для того, щоб він реалізовувався на практиці, а не був «мертвим» він повинен бути справедливим. У такому випадку він впливає на свідомість людей. У протилежному випадку виникає спротив. Якщо закон не правовий він втрачає своє значення.

На даний час ми є свідками відновлення справедливості в Україні. Президент України Володимир Зеленський вживає всі заходи для того, щоб відновити справедливість у нашій державі. Так, для прикладу, справа Віктора Медведчука та інших олігархів.

Слід зазначити, що на відміну від справедливості, ідея законності виникає тільки в державно-організованому суспільстві. Законність безпосередньо випливає із справедливості, тому між ними існує тісний 
взаємозв'язок. Кіпп Т. зазначає, що уже римлянам «не чужою була думка, яка постійно відроджувалася у всі епохи, що, крім права, яке той чи інший народ створює для себе, тобто крім позитивного права, існує ще право звичайне, jus naturae, jus natural» [5, c. 6].

Отже, в Основному Законі України закріплена віра у справедливість та законність, які гарантують права людини і громадянина. Проте проблемою $є$ те, що принцип справедливості та принцип законності реалізовуються лише формально і це призводить до правового нігілізму, міграції українців до розвинутих держав-членів Європейського Союзу, відтоку іноземних інвестицій.

\section{Література:}

1. Погребняк С. Закріплення основоположних принципів права в Конституції України. Вісник Академії правових наук України. 2009. № 4 (59). С. 31-39.

2. Івановська А. М. Законність, конституційна законність та конституційність як засади здійснення конституційного контролю: до питання співвідношення понять. Юридичний науковий електронний журнал. 2020. № 1. С. 43-46.

3. Баглай М. В., Туманов В. А. Малая энциклопедия конституционного права. М.: БЕК, 1998. 519 с.

4. Поленина С. В. Качество закона и эффективность законодательства. М. 1993. 56 с.

5. Кипп Т. История источников римского права. СПб.: Тип. Первой СПб. труд. артели, 1908. 156 с. 